\title{
Reproductive behavior of Leptodactylus mystacinus (Anura, Leptodactylidae) with notes on courtship call of other Leptodactylus species
}

\author{
Júlio C. de Oliveira Filho ${ }^{1} \&$ Ariovaldo A. Giaretta ${ }^{2}$
}

1. Rua Xavantes, 1047, 206, Lídice, 38408-082 Uberlândia, Minas Gerais, Brazil. (juliocesarfilho@yahoo.com.br)

2. Laboratório de Comportamento, Ecologia e Sistemática de Anuros Neotropicais, Universidade Federal de Uberlândia, Minas Gerais, Brazil. (thoropa@inbio.ufu.br)

\begin{abstract}
Here we present data on the reproductive behavior of Leptodactylus mystacinus (Burmeister, 1861), including details on courtship behavior. We also describe and compared the courtship calls of L. mystacinus, L. furnarius Sazima \& Bokermann, 1978 and Leptodactylus sp. ( $L$. aff. andreae). Field works were conducted in Uberlândia (central Brazil). During courtship, a female approaches a calling male and is led to a previously excavated chamber; a female can approach a silent male that beat his hands and/or feet on the ground as well. The courtship call of L. mystacinus consists of one single arch-shaped note (duration $=0.04$ s) repeated 258 times per minute; the courtship calls of L. furnarius ( $0.06 \mathrm{~s}, 84$ times per minute) and Leptodactylus sp. (0.15 s, 5 times per minute) also are archshaped. The courtship behavior of L. mystacinus is similar to that of other species of the L. fuscus (Schneider, 1799) group; unique to it is that males can beat his hands and/or feet on the ground while courting. The male behavior of conducting the female to a previously excavates chamber and the arch-shaped courtship call may represent other shared derived features of members of the L. fuscus group, including the former Adenomera species.
\end{abstract}

KEYWORDS. Brazilian savanna, foam nests, territoriality, vocalization, parental care.

RESUMO. Biologia reprodutiva de Leptodactylus mystacinus (Anura, Leptodactylidae) com notas sobre o canto de corte de outras espécies de Leptodactylus. Aqui apresentamos dados sobre o comportamento reprodutivo de Leptodactylus mystacinus (Burmeister, 1861), incluindo detalhes sobre o comportamento de corte; também descrevemos e comparamos o canto de corte de $L$. mystacinus, $L$. furnarius Sazima \& Bokermann, 1978 e Leptodactylus sp. (L. aff. andreae). O trabalho de campo foi realizado em Uberlândia (Central Brasil). Durante a corte, a fêmea aproxima-se de um macho que vocaliza e é levada para uma câmara previamente escavada; uma fêmea pode se aproximar de um macho silente que bate as mãos e/ou pés no solo repetidamente. O canto de corte de L. mystacinus consiste de uma única nota em forma de arco (duração $=0.04 \mathrm{~s}$ ) repetida 258 vezes por minuto; os cantos de corte de L. furnarius $(0.06 \mathrm{~s}$, 84 vezes por minuto) e Leptodactylus sp. (0.15 s, 5 vezes por minuto) também são em forma de arco. O comportamento de corte de $L$. mystacinus é similar ao de outras espécies do grupo de L. fuscus (Schneider, 1799); sendo exclusivo daquela espécie o fato de que os machos podem bater suas mãos e/ou pés no solo enquanto cortejam. O comportamento do macho de conduzir a fêmea para uma câmara previamente escavada e o canto de corte em forma de arco podem representar outras características derivadas compartilhadas pelos membros do grupo de L. fuscus, incluindo as antigas espécies de Adenomera.

PALAVRAS-CHAVE. Cerrado, ninhos de espuma, territorialidade, vocalização, cuidado parental.

As presently defined, the Leptodactylus (Fitzinger, 1826) species of the L. fuscus (Schneider, 1799) group build foam nests in excavated underground chambers (CEI, 1949; Martins, 1988; CALdWell \& LoPeZ, 1989; PisAnó et al., 1993; De La Riva, 1995; Crump, 1995; Almeida \& Angulo, 2002; GiaretTa \& KoKUBum, 2004) and have exotrophic tadpoles (Philibosian et al., 1974; Downie, 1984; De La Riva, 1995; PRADO et al., 2002; Giaretta \& KoKUbum, 2004). Tadpoles of five species of this group are known to be able to generate foam (Philibosian et al., 1974; Downie, 1984, 1989, 1990; CALDwell \& Lopez, 1989) a behavior also known to a few other leptodactylid frogs (Almeida \& Angulo, 2002; GiaretTA \& KoKUbum, 2004; KoKUbUm \& Giaretta, 2005). In three species of the L. fuscus group, including L. mystacinus (Burmeister, 1861), parental care has been observed (LESCURE, 1973; Solano, 1987; Cei, 1949; Crump, 1995; Giaretta \& Oliveira Filho, 2006). Herein we present data on the reproductive behavior of Leptodactylus mystacinus of a population from the State of Minas Gerais, including details on courtship behavior and territoriality. We test the foamgeneration abilities of the tadpoles of this species as well.
We also describe the courtship call of two other Leptodactylus species (one previously allocated in the former genus Adenomera (Steindachner, 1867) (KокUвUм \& GiARETTA, 2005)). Interspecific comparisons of this type of call and courtship behavior among leptodactylid frogs provide new insights on the status of the genus Leptodactylus in relation to Adenomera.

\section{MATERIAL AND METHODS}

We studied the behavior of Leptodactylus mystacinus in several localities in the municipality of Uberlândia, State of Minas Gerais, central Brazil, mainly around artificial ponds. This region was originally covered by Brazilian Cerrado (ARAúJo et al., 1997), a mosaic of open savanna, savanna/woodland, and dry forest ecosystems, which presently exists as fragments scattered across the landscape. The climate is the Aw type of Köppen, with high temperatures $\left(>20^{\circ} \mathrm{C}\right)$ and two welldefined seasons: rainy/warm from September to March and dry/mild from April to August. Annual mean 
precipitation is approximately $1,550 \mathrm{~mm}$, varying between 750 to 2,000 mm (GiaretTa \& Konubum, 2004).

To L. mystacinus, we followed reproductive activity weekly from October 2004 to March 2005, including dry months; sporadic observations were also performed between October 2003 and January 2004. During the breeding season, we carried out observations along the $24 \mathrm{~h}$ period to determine daily calling activity. We focused observations (MARTIN \& BATESON, 1986) on courtship and between-male agonistic interactions. We checked for further evidences of parental care by monitoring egg clutches for two consecutive nights after egg-laying. We refer to specific individuals based on their distinctive mottling pattern on back.

All measurements were taken with calipers to the nearest $0.1 \mathrm{~mm}$. We measured the snout-vent length of preserved adults and used t-Test (ZAR, 1984) to check for significance in sexual size dimorphism. Adult males were captured while calling; adult females were those bearing ripe eggs (> $3 \mathrm{~mm}$ ). For the description and measurements of underground chambers, we made casts by injecting liquid plaster through the chamber entrance. We measured entrance tunnel length as the largest measure from the external opening to the beginning of the main chamber. The chamber width was measured as the widest measure perpendicular to the length (according to the tunnel axis) and the height was the largest distance between the floor and roof; the tunnel length and width were measured in a similar way. Chamber volume (excluding entrance tunnel) was determined by measuring the volume of the casts using a graduated cylinder; prior to measurement the casts were hydrated for $6 \mathrm{~h}$.

We recorded vocalizations of $L$. mystacinus, $L$. furnarius (Sazima \& Bokermann, 1978) and Leptodactylus sp. (L. aff. andreae) from within $1 \mathrm{~m}$ from the calling males using a digital recorder $(44100 \mathrm{~Hz}, 16 \mathrm{bit})$, with a microphone. We analyzed calls with the Soundruler software (GRIDI-PAPP, 2004; version 0.9.4.1), using a Fast Fourier Transformation (FFT) with 256 points. We followed HEYER \& HEYER (2004) to describe call features. Courtship calls were recognized by directly observation of courting pairs.

We determined the number of offspring per reproductive event by counting eggs and early tadpoles ( $<15 \mathrm{~mm}$ ) found within chambers. In the field we followed a clutch of known age to determine the maximum development tadpoles reached inside the chamber and followed a cohort of known age to estimate duration of larval aquatic phase.

References to larval stages follow GOSNER (1960). We determined if tadpoles (stage 24) were able to generate foam by carefully washing them (declorinated tap water) from their original foam. To this test we reared three groups of 50 tadpoles, from three egg clutches, in plastic $(30 \mathrm{~mm}$ diameter) tubes kept in a laboratory under a natural temperature/lightning regime. The tubes were kept in humid conditions, but had no free water in which tadpoles could swim. We monitored the tadpoles every four hours for $48 \mathrm{~h}$ after tube establishment. As a control for the laboratory conditions, we performed the same procedure with tadpoles of L. fuscus, a species known to foam under laboratory conditions (GIARETTA \& KoKUbum, 2004).

Voucher specimens are in the frog collection of the Museu de Biodiversidade do Cerrado, Universidade Federal de Uberlândia, Uberlândia, State of Minas Gerais, Brazil (L. mystacinus AAG-UFU 2399, 3058, 3057, 3064, 3109, 3060).

\section{RESULTS}

In our study area, females L. mystacinus were about $10 \%$ larger (mean $\mathrm{SVL}=57.9 \mathrm{~mm}, \mathrm{SD}=3.1, \mathrm{~N}=6$ ) than males (mean $\mathrm{SVL}=52.9 \mathrm{~mm}, \mathrm{SD}=2.8, \mathrm{~N}=7)(\mathrm{t}=3.05, \mathrm{df}$ $=11, \mathrm{p}=0.01)$. Males also differed from females by having a shovel-shaped nose and, often, a darker gular region. Males started calling with the first (even weak) rains of October and finished in mid-March. During the peak of calling activity (October-December), males started calling at about one hour before sundown (around 18:00 h) and continued until around the middle $(10: 00 \mathrm{~h})$ of the following morning; out of these months calling generally ceased by around sunrise $(5: 30 \mathrm{~h})$.

Most males called from the border of artificial shallow ( $<40 \mathrm{~cm}$ deep), temporary ponds or rain-drainage channels, amidst dense tuffs of Brachiaria sp. (Poaceae), an exotic grass which grows less than one meter tall. Males could also call from below pieces of $\operatorname{wood}(n=3)$ around $(<8 \mathrm{~m})$ ponds or inside the chamber $(n=4)$. Males were rarely $(n=2)$ heard calling along palm grove marshes (veredas). Eggs were laid within underground chambers, amidst a white foam $(n=25)$. The chambers $(n=35)$ were at the bottom or along the margins ( $<1 \mathrm{~m}$ away) of the ponds/channels the males called from. The chambers were either excavated in bare (exposed to sunlight) soil or under grass tuffs; we once found five independent chambers under a dense pile of cut grass ( $1.5 \mathrm{~m}$ diameter, $50 \mathrm{~cm}$ high).

At the beginning of chamber digging $(n=4)$, the male stretched a little his hind limb raising the posterior half of his body and, with the snout, pressed earth in front of him. With the snout in the earth, he forced his head up, making the entrance broader; sporadically he threw earth back with his hands. Between 3-20 min after excavation began, the male disappeared into the ground.

During courtship ( $n=15,13$ complete observations) a female approaches a calling male and is led to a previously excavated chamber (0-8 $\mathrm{m}$ away). Along the way, the female touch the male's body with her snout and he releases courtship calls (described below). When the couple reach the chamber entrance, the male enter first and is immediately followed by the female $(n=12)$. In a variation of this pattern, a female can approach a male that is silent but repeatedly beat his hands and/or feet on the ground $(n=2)$. In two cases, the male apparently excavated the chamber during the courtship. After a female enters a chamber, the male either came back $(n=4)$ or not $(n=5)$ to obliterate the entrance with his snout out.

The chambers (Figs. 1, 2, 4 and 5) were approximately spherical $(\mathrm{n}=3)$, with a mean length of $90.8 \mathrm{~mm}(\mathrm{SD}=4.3)$, mean width of $88.7 \mathrm{~mm}(\mathrm{SD}=2.5)$ and 
mean height of $64.3 \mathrm{~mm}(\mathrm{SD}=4.2)$. Entrance tunnels were, on average, $56.5 \mathrm{~mm}$ long $(\mathrm{SD}=13.6), 27.7 \mathrm{~mm}$ wide $(\mathrm{SD}=$ $3.3)$, and $16.8 \mathrm{~mm}(\mathrm{SD}=3.4)$ tall. Mean chamber volume (excluding the tunnel) was $273 \mathrm{ml}(\mathrm{SD}=18.9)$.

Adults were found during the day sheltering amidst the roots of grass tufts ( $n=6$, at least three males), in cracks of drying mud $(n=4)$, and within underground chambers $(n=3)$.

None of the 15 egg clutches monitored during our study had guarding individuals nearby during the two nights following egg-laying. In the two instances where we found adults in close range of recently-laid egg clutches, clutches were laid in multiple chamber situations (three chambers accessed through a single tunnel). In these situations, adult behavior varied: in one case a male called from within a neighboring chamber and in the other there was a male and an egg-bearing female in one of the neighboring chambers. We found just two of these 15 chambers capped with earth.

Agonistic interactions $(n=5)$ occurred when silent or calling males (invaders) approached $(<60 \mathrm{~cm})$ calling sites or chambers of resident males. A resident reacted either by emitting territorial calls ( $\mathrm{n}=3$ cases) (described below) and/or repeatedly beating hands and/or feet on the ground $(\mathrm{n}=1)$. The invader responded either with territorial calls $(n=2)$ or by beating his hands/feet $(n=1)$ on the ground. The resident or the invader either run away $(n=2)$ or, in cases were both males resisted fleeing, a fight started $(n=3)$. During fights males hit each other with snout, feet, and hands. The fights stopped when one combatant fled $(\mathrm{n}=3)$.

Offspring (eggs or nestling tadpoles) number varied between 159 and $627($ mean $=401, \mathrm{SD}=133, \mathrm{~N}=15)$. Eggs were pale yellow and the yolk portion measured $4.1 \mathrm{~mm}$ in diameter $(\mathrm{SD}=0.3, \mathrm{~N}=25$ eggs, $\mathrm{N}=5$ eggs from 5 clutches).

After 15 days, chambering tadpoles reached stage 27 and had an average total length of $11.6 \mathrm{~mm}(\mathrm{SD}=0.3$, $\mathrm{n}=9, \mathrm{n}=1$ nest); at this stage individuals had low vitelinic reserves. Once in ponds, tadpoles lasted 13 days to complete metamorphosis. Maximal TL (Gosner 41) was $49 \mathrm{~mm}$. Newly metamorphosed juveniles were between 15.6-22.0 mm SVL ( mean $=19.1 \mathrm{~mm}, \mathrm{SD}=2.2, \mathrm{n}=17$ ).

All tested groups of tadpole generated new foam, which was produced when individual tadpoles came to the surface and released bubbles through the mouth. Newly produced foam was less dense than that produced by the parents.

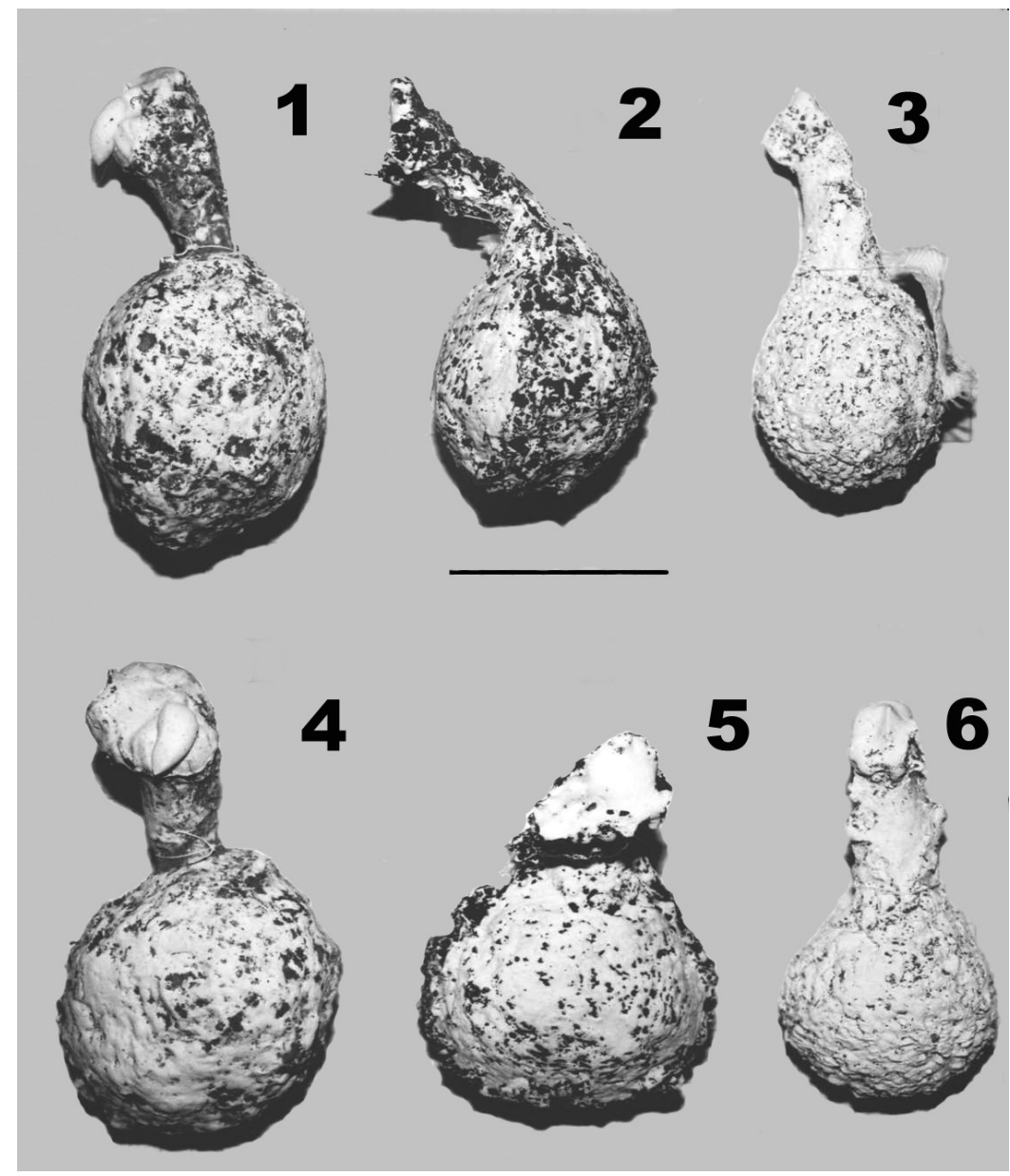

Figs. 1-6. Plaster moulds of underground chambers: 1-2 (lateral views), and 4-5 (upper views), two chambers of Leptodactylus mystacinus (Burmeister, 1861); 3 (lateral) and 6 (upper view), one chamber of L. fuscus (Schneider, 1799), presented for comparative purposes. Samples from Uberlândia, State of Minas Gerais, central Brazil. Scale, $70 \mathrm{~mm}$. 
The advertisement call of L. mystacinus (Figs. 710) consists of a single note repeated at an average of 213 times per minute ( $\mathrm{SD}=78, \mathrm{n}=18$ calls, $\mathrm{n}=3$ males). $\mathrm{A}$ single harmonic is evident and the dominant and fundamental frequencies are coincident, with energy peak around $2,239 \mathrm{~Hz}$. The call duration is $0.04 \mathrm{~s}(\mathrm{SD}=0.0)$ and the mean interval between calls is $0.18 \mathrm{~s}(\mathrm{SD}=0.12)$.

During our study, the territorial call (Figs. 11-14) was heard only when two males were in close range $(<60$ $\mathrm{cm})$. This call is composed of a single note, repeated 246 times per minute. Two harmonics can be recognized and the fundamental and the dominant frequencies are coincident, with an energy peak around $2,067 \mathrm{~Hz}$; the second harmonic (not evident in Figs. 11-14), has a frequency range between $3,643-3,790 \mathrm{~Hz}$. The call has a descendent modulation and lasts $0.04 \mathrm{~s}(\mathrm{SD}=0.0, \mathrm{n}=10$ calls, 1 male); the between-call interval is $0.09 \mathrm{~s}(\mathrm{SD}=0.0$, $\mathrm{n}=10$ calls from 1 male). Territorial calls were regularly intercalated with advertisement calls.

The courtship call (Figs. 15-18) consists of a single note, repeated 258 times per minute. Two harmonics are evident. The fundamental frequency is the emphasized and is coincident with the dominant. The fundamental frequency has an energy peak around $2,928 \mathrm{~Hz}$. The second harmonic has a frequency range between 5,690$6,630 \mathrm{~Hz}$. The call is arch-shaped, with an ascendant modulation to the middle of the note and descendent beyond this point. The duration of the call is $0.04 \mathrm{~s}(\mathrm{SD}=$
$0.0, \mathrm{n}=10$ calls, 1 male) between-call interval is $0.24 \mathrm{~s}$ (SD $=0.19, \mathrm{n}=10$ calls, 1 male). Courtship calls were sometimes intercalated with advertisement calls.

The courtship call of L. furnarius (Figs. 19-22; compare with the advertisement call, figure 5 in GIARETTA \& Kокивим, 2004) consists of a single note, repeated 84 times per minute. A single harmonic is evident and the dominant and fundamental frequencies are coincident, with energy peak around $3,273 \mathrm{~Hz}$. The call is arch-shaped, with an ascendant modulation to the middle of the note and descendent beyond this point. The duration of the call is $0.06 \mathrm{~s}(\mathrm{SD}=0.01, \mathrm{n}=10$ calls, 1 male) between-call interval is $0.14 \mathrm{~s}(\mathrm{SD}=0.03, \mathrm{n}=10$ calls, 1 male). Courtship calls were sometimes intercalated with advertisement calls.

The courtship call of Leptodactylus sp. (Figs. 2325; compare with the advertisement call, figure 4 in KonUbum \& GiaretTA, 2005) sounds like a weak chick chirp released at a rate of five calls per minute. Two harmonics are evident. The fundamental frequency is the emphasized and is coincident with the dominant. The fundamental frequency has an energy peak around 2,300 $\mathrm{Hz}$. The second harmonic has a frequency range between $3,986-4,820 \mathrm{~Hz}$. The call is arch-shaped, with an ascendant modulation to the middle of the note and descendent beyond this point, and lasts about $0.15 \mathrm{~s}(\mathrm{SD}=15, \mathrm{n}=5$ calls, 1 male). While emitting courtship call, males can release pulsed notes that can be regarded as variants of the advertisement call.
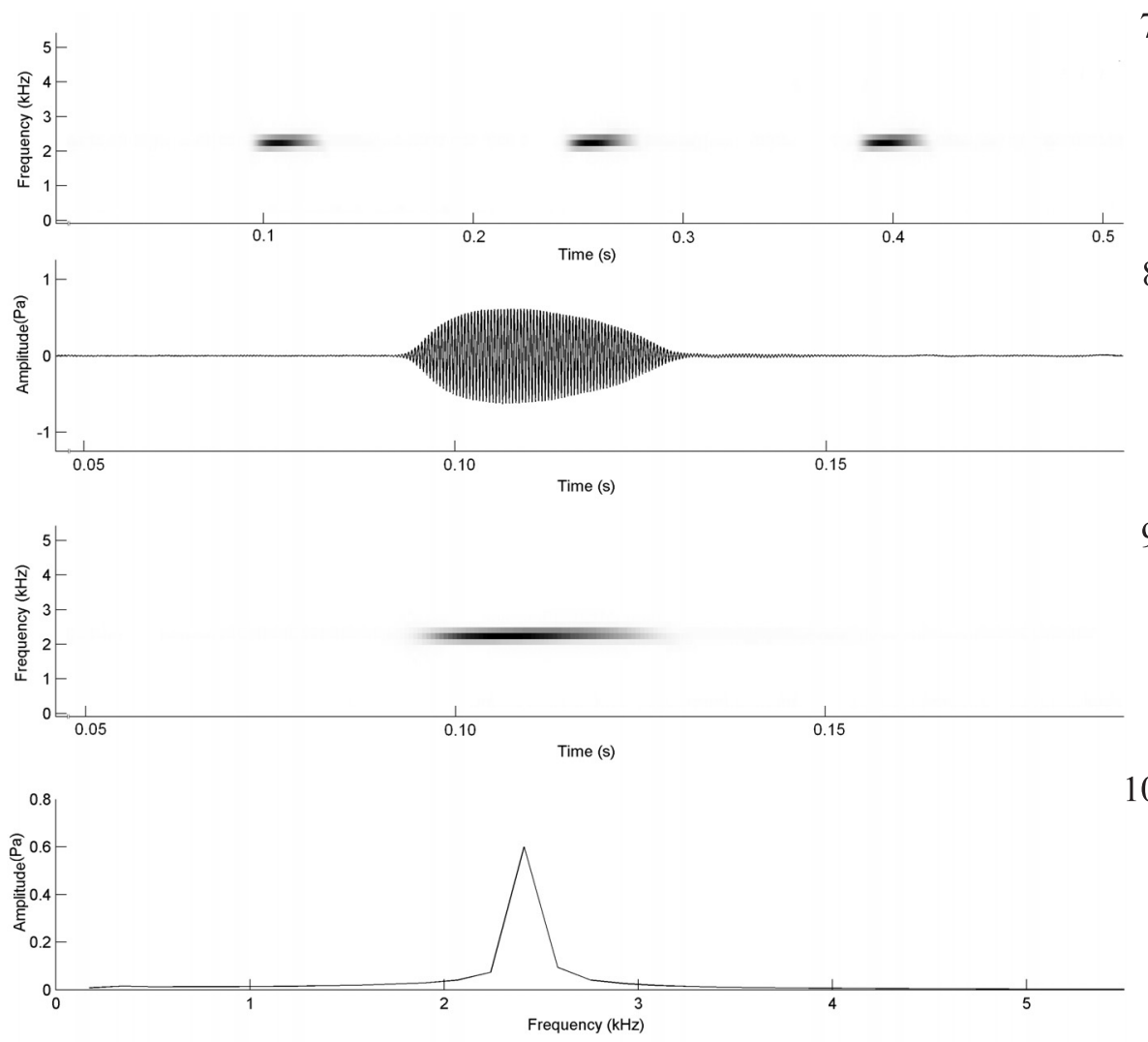

Figs 7-10. Advertisement calls of Leptodactylus mystacinus (Burmeister, 1861). 7, Audiospectrogram of a sequence of three calls; 8, Oscilogram; 9, Audiospectrogram; 10, Frequency spectrum of the first call in Fig. 7. AAG sound file Leptodmystacinusmg2AAGd; Nov 28 2003; 18:50 h; air temperature $23.4^{\circ} \mathrm{C}$; unvouchered record. Specimen from Uberlândia, State of Minas Gerais, central Brazil. 

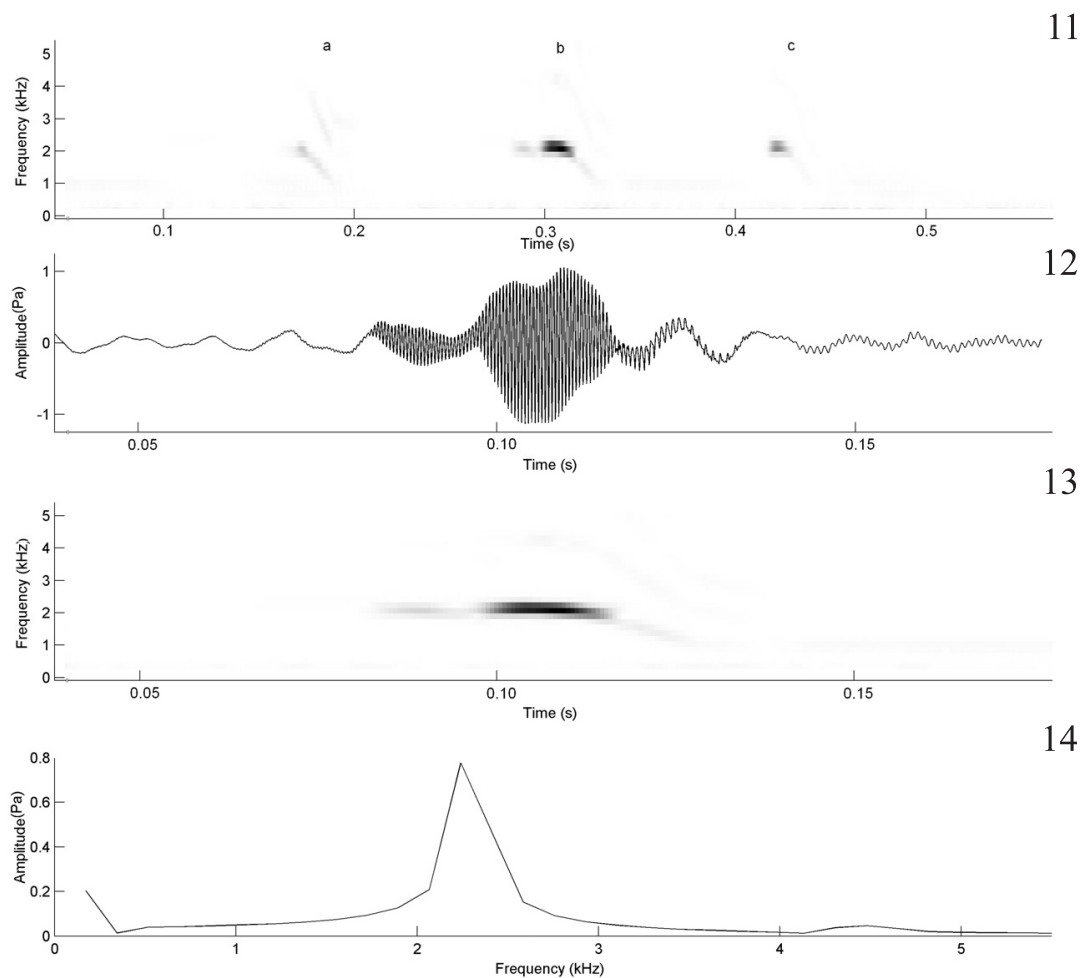

Figs 11-14. Territorial call of Leptodactylus mystacinus (Burmeister, 1861). 11, Audiospectrogram of a sequence of three calls from two individuals (individual 1, calls a and c, individual 2, call b); 12, Oscilogram; 13, Audiospectrogram; 14, Frequency spectrum of call b. AAG sound file Leptodmystacinusmg3AAGd; November 13 2003; 22:22 h; air temperature $21.5^{\circ} \mathrm{C}$; water $23.5^{\circ} \mathrm{C}$; unvouchered record. Specimen from Uberlândia, State of Minas Gerais, central Brazil.
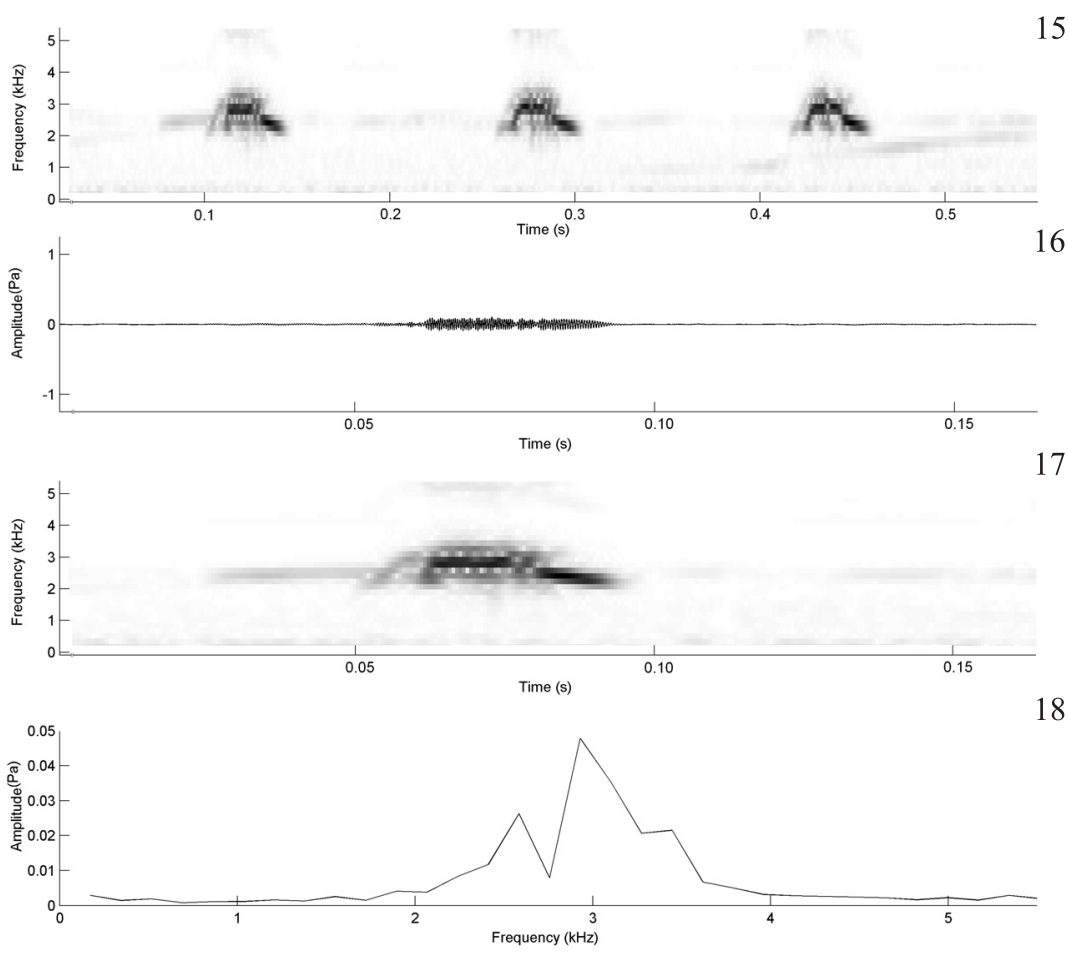

Figs. 15-18. Courtship calls of Leptodactylus mystacinus (Burmeister, 1861). 15, Audiospectrogram of a sequence of three calls; 16, Oscilogram; 17, Audiospectrogram; 18. Frequency spectrum of the first call in Fig. 15. AAG sound file Leptodmystacinus AAGd2; October 23 2004; $21: 45$ h; air temperature $20.9^{\circ} \mathrm{C}$; water $22.3{ }^{\circ} \mathrm{C}$; unvouchered record. Specimen from Uberlândia, State of Minas Gerais, central Brazil. 

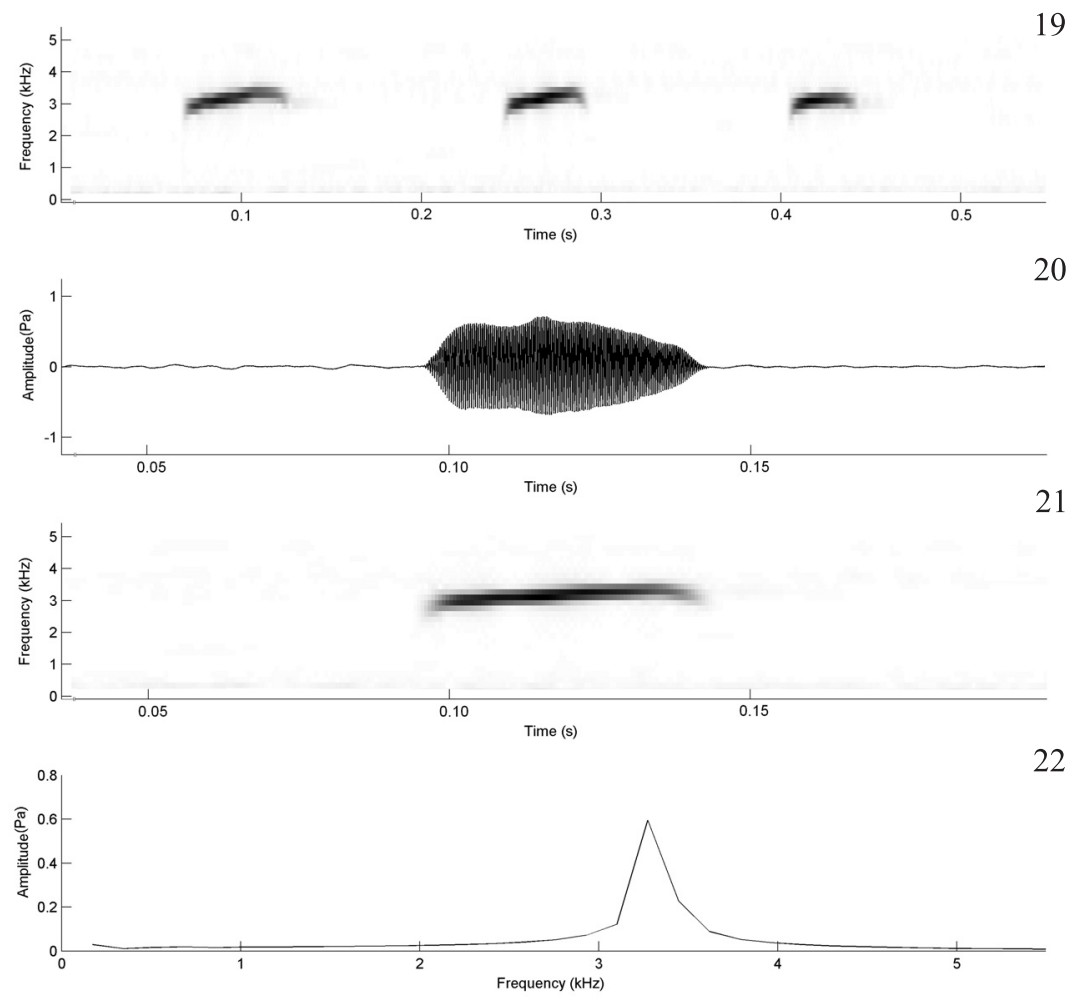

Figs. 19-22. Courtship calls of Leptodactylus furnarius (Sazima \& Bokermann, 1978). 19, Audiospectrogram of a sequence of three calls; 20, Oscilogram; 21, Audiospectrogram; 22, Frequency spectrum of the second call in Fig. 19. AAG sound file Leptodfurnarmg5bAAGd; December 09 2005; 21:45 h; air temperature $23.3^{\circ} \mathrm{C}$; unvouchered record. Specimen from Uberlândia, State of Minas Gerais, central Brazil.
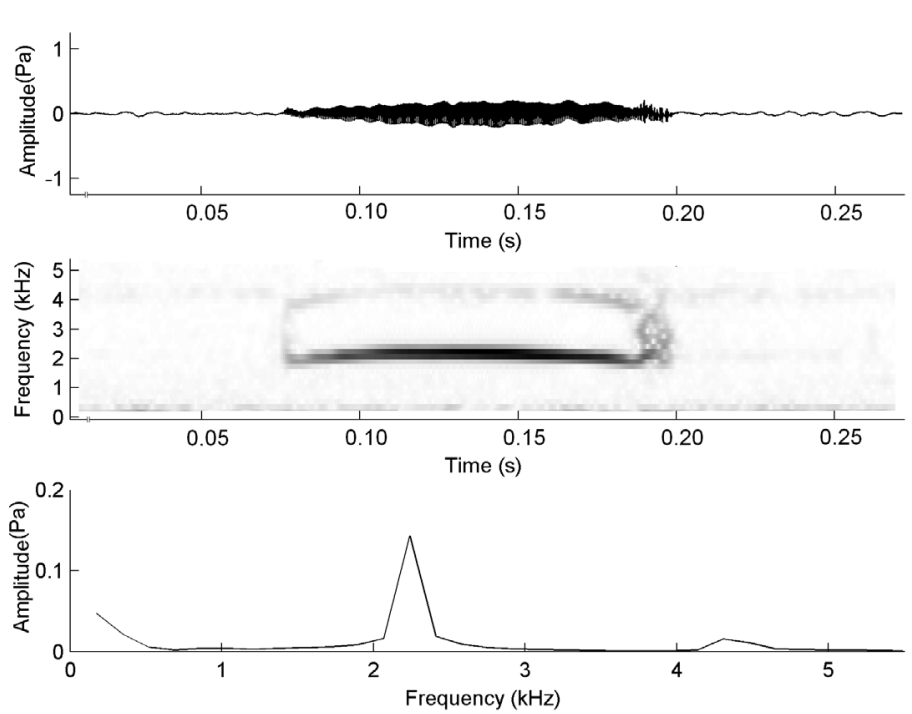

Figs. 23-25. Courtship call of Leptodactylus sp.. 23, Oscilogram; 24, Audiospectrogram; 25, Frequency spectrum of a single call. AAG sound file Adenomspmg4AAGd; October 06 2005; 20:00 h; air temperature $22.5^{\circ} \mathrm{C}$; unvouchered record. Specimen from Uberlândia, State of Minas Gerais, central Brazil.

\section{DISCUSSION}

The breeding season of Leptodactylus mystacinus ends in March, one or two months before the end of the rainy season. This may allow individuals to store reserves and endure the coming dry season and/or reduce tadpole loss in periods of more erratic rainfall. This species breeds mainly at the margins of artificial, temporary water bodies (ABRUNHOSA et al., 2001; present study), but permanent water courses can also be used as well (STRANECK et al., 1993; present study).

Chamber shape is quite variable among the species of Leptodactylus of the L. fuscus group. The underground chamber of L. bufonius (Boulenger, 1894) (CEI, 1949) is 
jar-shaped, while those of L. mystacinus (present work) and L. fuscus (GiaretTA \& KoKubum, 2004) contain an access tunnel. In L. furnarius and in Leptodactylus sp. (Giaretta \& Kokubum, 2004; Kokubum \& Giaretta, 2005), the chambers have no entrance tunnel. TolEDo et al. (2005) describe a long-tunneled (gallery) chamber for $L$. mystaceus (Spix, 1824). Multiple chambers were rare in $L$. mystacinus and may be related to territoriality and to a possible scarcity of proper places for chamber-digging. Besides L. mystacinus, multiple chambers were also described as a variation in L. mystaceus (TOLEDo et al., 2005; ARZABE \& PRADO, 2006), L. fuscus, and L. notoaktites (Heyer, 1978 ) (ARZABE \& PRADO, 2006).

Giaretta \& Oliveira Filho (2006) reported on an adult $L$. mystacinus repairing a damaged chamber the night after egg-laying. In the present study we did not find further direct evidence of parental care in this species. The presence of calling males in chambers adjacent to egg clutches may also be indicative of parental care, as occurs in some populations of L. fuscus (LESCURE, 1973; SolAnO, 1987). CEI (1949) and CRUMP (1995) regarded the female L. bufonius behavior of sealing the chamber entrance with mud immediately after egg-laying as parental care; READING \& JOFRÉ (2003) also observed this behavior but not related it to carrying behavior. In our study, we could not determine if sealed chambers were capped by one of the parents. We conclude that parental care is facultative in L. mystacinus and relatively rare when compared to some populations of L. fuscus (Lescure, 1973; Solano, 1987).

As L. fuscus (Rossa-Feres et al., 1999), males $L$. mystacinus can use chambers as diurnal shelters, what, in both species, may be related to territoriality and the difficulties the males have to come back to their territory every night; ARZABE \& PRADO (2006) interpreted that this behavior can confer protection for adults from predators.

The courtship behavior of L. mystacinus was similar to that described for L. fuscus (MARTINS, 1988; FREITAS et al., 2001), L. furnarius (GIARETTA \& KOKUBUM, 2004) and Leptodactylus sp. (KoKUBUM \& GiARETTA, 2005). In all these species, the male leads the female towards the chamber and may return to block the tunnel entrance with his head. Unique to L. mystacinus was the observation that males apparently can dig the chamber (underground behavior was difficult to access) and beat his hands and/or feet on the ground while courting.

Males L. mystacinus may beat their hands and/or feet on the ground while courting or in anticipation to fights. Pounding the ground like this may result in seismic signals and be important in conspecific communication, as has been reported in L. albilabris (Günther, 1859) (LewIS \& NARINS, 1985; NARINS, 1990; LeWIS et al., 2001). Another possibility is that the limb movements represent visual displays, which may be important to communication even in nocturnal species (ABRUNHOSA \& Wogel, 2004; Wogel et al., 2004; Hartmann et al., 2005).

Like in our study, agonistic between-males interactions (fights and territorial calls) has been observed in L. fuscus (MARTINS, 1988; RosSA-FERES et al., 1999; FreITAS et al., 2001) and Leptodactylus sp. (KoKUBUM \& GiARETTA, 2005).
We found that L. mystacinus tadpoles generated foam releasing bubbles through the mouth, a behavior shared among several species in the L. fuscus group (Downie, 1984, 1989; CALDwEll \& LoPEZ, 1989; GiARETTA \& Konubum, 2004), Leptodactylus sp. (Koкubum \& Giaretta, 2005), and L. labyrinthicus (Spix, 1824) (KoKubum \& GiaretTA, 2005). In all these species, the tadpole foam may enhance the efficiency of respiration and excretion by avoiding tadpole compaction on the bottom of the chamber (DownIE \& SMITH, 2003; KoKUBUM \& GiaretTA, 2005). Foam-generating tadpoles appear to be a shared derived feature of the L. fuscus (including former Adenomera species) and L. pentadactylus (Laurenti, 1768) species groups (DAVIES et al., 2000; GIBSON \& Buley, 2004; Kokubum \& Giaretta, 2005; present study).

The advertisement call of L. mystacinus we described is similar to that from other Brazilian locality, such as Rio de Janeiro (ABRUnhosa et al., 2001), as well as from more distant populations in Argentina (BARRIO, 1965; StRANECK et al., 1993) and Paraguay (HEYER et al., 2003). Just one harmonic was evident in the advertisement call we described, similar to previous studies (HEYER et al., 2003). Two (ABRUNHOSA et al., 2001) and three (BARRIO, 1965) harmonics also have been reported, but it is unclear if these differences are real or due to different recording methods and analysis. ABRUNHOSA et al. (2001) described two distinct call types for L. mystacinus, but could not determine their function; no call we found is similar to those they recognized.

Males of several species of Leptodactylus of the L. fuscus group (FREITAS et al., 2001; present study), Leptodactylus sp. (KoKUBum \& GiaretTA, 2005), and L. labyrinthicus (ZINA \& HADDAD, 2005) emit courtship calls. This kind of call is unknown to species of the $L$. melanonotus (Hallowell, 1861)/L. ocellatus (Linnaeus, 1758) groups (HEYER, 1974). Males of L. fuscus release territorial and courtship calls while courting females (Freitas et al., 2001). Freitas et al. (2001) described an arch-shaped call as being territorial; MARTINS (1988) described a different call type as the territorial of this species. We regard the arch-shaped calls we described as the courtship call of L. mystacinus, L. furnarius, and Leptodactylus sp..

KoKUBum \& GiaRETTA (2005) listed behaviors such as laying eggs in underground chambers and foamproducing tadpoles as evidence for the paraphyletic nature of the genus Leptodactylus in relation to Adenomera. The male behavior of conducting female to the chamber and the arch-shaped courtship call may represent other possible shared, derived features between all species of Leptodactylus of the L. fuscus group, including all former Adenomera species. For a contrary interpretation of the evolution of such complex reproductive behaviors see DE SÁ et al. (2005).

Acknowledgements. Fellowship (AAG) and financial support by CNPq and FAPEMIG. The senior author thanks J. C. Oliveira for a financial support. H. C. M. Costa, A. P. Rodrigues, R. C. Costa, D. R. Silva, and C. T. Lopes helped in field work. K. G. Facure, R. P. Bastos, W.R. Silva, C. P. A. Prado and W. Hödl critically read the draft. H. Wogel and S. Scrocchi provided some hard-to-find papers 


\section{REFERENCES}

Abrunhos A, P. A. \& Wogel, H. 2004. Breeding behavior of the leaf-frog Phyllomedusa burmeisteri (Anura: Hylidae). Amphibia-Reptilia 25:125-135.

Abrunhosa, P. A.; Wogel, H. \& Pombal JR., J. P. 2001. Vocalização de quatro espécies de anuros do estado do Rio de Janeiro, sudeste do Brasil (Amphibia, Hylidae, Leptodactylidae). Boletim do Museu Nacional do Rio de Janeiro 472:1-12.

Almeida, A. P. \& Angulo, A. 2002. Adenomera aff. marmorata (NCN) Reproduction. Herpetological Review 33(3):197-198.

Araújo, G. M.; Nunes, J. J.; Rosa, A. G. \& Resende, E. J. 1997. Estrutura comunitária de vinte áreas de Cerrados residuais no município de Uberlândia, MG. Daphne 7:7-14.

Arzabe, C. \& Prado, C. P. A. 2006. Distinct Architectures of Subterranean Nests in the Genus Leptodactylus of the fuscus Group. Herpetological Review 37(1):23-26.

Barrio, A. 1965. Afinidades del canto nupcial de las especies cavícolas del genero Leptodactylus (Anura - Leptodactylidae). Physis 70:401-410.

Caldwell, J. P. \& Lopez, P. T. 1989. Foam-generating behavior in tadpoles of Leptodactylus mystaceus. Copeia 1989(2): 498-502.

CeI, J. M. 1949. Costumbres nupciales y reproducción de un batracio característico chaqueño (Leptodactylus bufonius Boul.). Acta Zoologica Lilloana 8:105-110.

CRUMP, M. L. 1995. Leptodactylus bufonius (NCN). Reproduction. Herpetological Review 26(2):97-98.

Davies, S. L.; Davies, R. B.; James, A. \& Talyn, B. C. P. 2000. Reproductive behavior and larval development of Leptodactylus fallax in Dominica, West Indies. Herpetological Review 31(4):217-220.

De La Riva, I. 1995. A new reproductive mode for the genus Adenomera (Amphibia: Anura: Leptodactylidae): taxonomic implications for certain Bolivian and Paraguayan populations. Studies on Neotropical Fauna and Environment 30(1):15-29.

De Sá, R. O.; Heyer, W. R. \& Camargo, A. 2005. A Phylogenetic analysis of Vanzolinius Heyer, 1974 (Amphibia, Anura, Leptodactylidae): Taxonomic and life history implications. Arquivos do Museu Nacional, Rio de Janeiro 63(4):707-726.

Downie, J. R. \& Sмiтh, J. 2003. Survival of larval Leptodactylus fuscus (Anura: Leptodactylidae) out of water: developmental differences and interspecific comparisons. Journal of Herpetology 37(1):107-115.

Downie, J. R. 1984. How Leptodactylus tadpoles make foam, and why. Copeia 3:778-780.

1989. Observations of the foam-making Leptodactylus fuscus tadpoles. Herpetological Journal 1:351-355.

1990. Temporal changes in the behavior of foam-making Leptodactylus fuscus tadpoles. Herpetological Journal 1:498-500.

Freitas, E. F. L.; Spirandeli-Cruz, E. F. \& Jim, J. 2001. Comportamento reprodutivo de Leptodactylus fuscus (Schneider, 1799) (Anura: Leptodactylidae). Comunicações do Museu de Ciências e Tecnologia 14(2):121-132.

Giaretta, A. A. \& Konubum, M. N. C. 2004. Reproductive ecology of Leptodactylus furnarius Sazima \& Bokermann, 1978, a frog that lays eggs in underground chambers (Anura: Leptodactylidae). Herpetozoa 16(3/4):115-126.

Giaretta, A. A. \& Oliveira Filho, J. C. 2006. Leptodactylus mystacinus (Shovel-Nosed Frog). Parental care. Herpetological Review 37(2):204.

Gibson, R. C. \& Buley, K. R. 2004. Maternal care and obligatory oophagy in Leptodactylus fallax: a new reproductive mode in frogs. Copeia 2004(1):128-135.

GosNER, K. L. 1960. A simplified table for staging anuran embryos and larvae with notes on identification. Herpetologica 16:183-190.

Gridi-Papp, M. 2004. Sound Ruler. V0941. Available at: <http:/ /soundruler.sourceforge.net> Access on: 10.10.2005.

Hartmann, M. T.; Giasson, L. O. M.; Hartmann, P. A. \& Haddad, C. F. B. 2005. Visual communication in Brazilian species of anurans from the Atlantic forest. Journal of Natural History 39(19):1675-1685

Heyer, M. M.; Heyer, W. R.; Spear, S. \& De Sá, R. O. 2003. Leptodactylus mystacinus (Burmeister) mustached frog. Catalogue of American Amphibians and Reptiles 767:1-11.

Heyer, W. R. \& Heyer, M. M. 2004. Leptodactylus furnarius Sazima and Bokermann Cerrado Oven Frog. Catalogue of American Amphibians and Reptiles 785:1-5.

Heyer, W. R. 1974. Relationships of the marmoratus species group (Amphibia, Leptodactylidae) within the subfamily Leptodactylidae. Contributions to Science Natural History Museum Los Angeles County 253: 1-50.

Kokubum, M. N. C. \& Giaretta, A. A. 2005. Reproductive ecology and behavior of a species of Adenomera (Anura, Leptodactylinae) with endotrophic tadpoles: systematic implications. Journal of Natural History 39(20):1745-1758.

Lescure, J. 1973. Contribution a l'étude des amphibiens de guyane française II. Leptodactylus fuscus (Schneider). Observations écologiques et éthologiques. Annales du Muséum d'Histoire Naturelle de Nice 1:91-100.

Lewis, E. R. \& Narins, P. M. 1985. Do frogs communicate with seismic signals? Science 227:187-189.

Lewis, E. R.; Narins, P. M.; Cortopassi, K. A.; Yamada, W. M. Poinar, E. H.; Moore, S. W. \& Yu, X. L. 2001. Do male whitelipped frogs use seismic signals for intraspecific communication? American Zoologist 41:1185-1199.

MARTIN, P. \& BATESON, P. 1986. Measuring behavior: an introduction guide. Cambridge, Cambridge University. 200p

Martins, M. 1988. Biologia reprodutiva de Leptodactylus fuscus em Boa Vista, Roraima (Amphibia: Anura). Revista Brasileira de Biologia 48(4):969-977.

Narins, P. M. 1990. Seismic communication in anuran amphibians. Bioscience 40(4):268-274

Philibosian, R.; Ruibal, R.; Shoemaker V. H. \& Mcclanahan, L. L. 1974. Nesting behavior and early larval life of the frog Leptodactylus bufonius. Herpetologica 30:381-386.

Pisanó, A.; Rengel, D. \& Lavilla, E. D. 1993. Le nid souterrain comme chambre nuptiale pour um Amphibien d'Argentine. Revue française of Aquariologie 19(4):125-126.

Prado, C. P. A.; Uetanabaro, M. \& Haddad, C. F. B. 2002. Description of a new reproductive mode in Leptodactylus (Anura, Leptodactylidae), with a review of the reproductive specialization toward terrestriality in the genus. Copeia 2002(4): $1128-1133$.

Reading, C. J. \& Jofré, G. M. 2003. Reproduction in the nest building viscacheras frog Leptodactylus bufonius in central Argentina. Amphibia-Reptilia 24:415-427.

Rossa-Feres, D. C.; Menin, M. \& Izzo, T. J. 1999. Ocorrência sazonal e comportamento territorial em Leptodactylus fuscus (Anura, Leptodactylidae). Iheringia, Série Zoologia, 87:93-100.

Solano, H. 1987. Algunos aspectos de la biología reproductiva del sapito silbador Leptodactylus fuscus (Schneider) (Amphibia: Leptodactylidae). Amphibia-Reptilia 8:111-128.

Straneck, R.; Oledo, E. V. \& Carrizo, G. R. 1993. Catálogo de voces de anfibios argentinos. Parte 1. Buenos Aires: L. O L. A. $127 \mathrm{p}$.

Toledo, L. F.; Castanho, L. M. \& Haddad, C. F. B. 2005 Recognition and distribution of Leptodactylus mystaceus (Anura, Leptodactylidae) in the state of São Paulo, southeastern Brazil. Biota Neotropica 5(1). Available at: <http:// www.biotaneotropica.org.br/v5n $1 / \mathrm{pt} / \mathrm{ab}$ stract? article+ BN00505012005.> Access on: 23.10.2005

Wogel, H.; Abrunhosa, P. A. \& Pombal JR., J. P. 2004. Vocalizations and aggressive behavior of Phyllomedusa rohdei (Anura: Hylidae). Herpetological Review 35(3):239-243

Zar, J. H. 1984. Bioestatistical Analysis. New Jersey, PrenticeHall. 712p.

ZINA, J. \& HADDAD, C. F. B. 2005. Reproductive activity and vocalizations of Leptodactylus labyrinthicus (Anura, Leptodactylidae) in southeastern Brazil. Biota Neotropica 5(2). Available at: <http://www.biotaneotropica.org.br/v5n2/ pt/abstract?article+BN00605022005> Access on: 23.10.2005 